\title{
The Burden Of Identity: Responding To Product Boycotts In The Middle East
}

Kjell Knudsen, University of Minnesota Duluth, USA Praveen Aggarwal, University of Minnesota Duluth, USA Ahmed Maamoun, University of Minnesota Duluth, USA

\begin{abstract}
Drawing from four different case studies of multinational corporations in the Middle East, we present a framework for understanding the phenomenon of product boycotts driven by sociopolitical reasons. We present three sets of actions that trigger boycott calls: government actions, corporate actions, and individual actions. The strategies used by boycott organizers to generate awareness for their campaign and to manage media usage to target desired audiences are also discussed. We review a number of strategies available to multinationals to respond to boycott calls.
\end{abstract}

Keywords: Product Boycotts, Boycott Triggers, Strategies for Handling Boycotts, International Marketing

\section{INTRODUCTON}

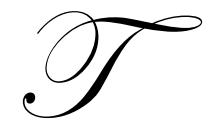

he Coca-Cola Company and our products are often regarded as American. But the fact is that The Coca-Cola Company is a truly international company, operating worldwide in more than 200 countries. The Coca-Cola business in each country is a local business. Coca-Cola beverages are produced, sold and distributed by authorized local bottling partners who own and operate bottling plants and sales/distribution centers, employing one million local citizens - 90\% outside the United States and nearly all of them citizens of other countries... Given the local nature of our business, we believe that calls for boycotts of our products are not the appropriate way to further any causes, as they primarily hurt the local economy, local businesses and local citizens. Spreading such allegations is an attempt to exploit a delicate situation in the Middle East." [from The Coca-Cola Company's web site: "Middle East Rumors"]

While the right to vote in political elections is reserved exclusively for the citizens of a country, noncitizens have increasingly made "voting by their wallet" a potent mechanism for expressing their opinions, disagreements, and frustrations pertaining to actions taken by peoples and governments in other countries. Commonly referred to as product boycotts or consumer boycotts, such calls for action target products and services of one or more organizations whose identity can be linked to the offending country. Formally, a boycott has been defined as "an attempt by one or more parties to achieve certain objectives by urging individual consumers to refrain from making selected purchases in the marketplace" (Friedman 1985, p. 97).

The objective of this study is to develop insights regarding product boycotts from a dual perspective: how do organizers of boycotts generate participation in a boycott and how do corporations respond to minimize the impact of such boycott calls. In order to meet the objectives of this study, we investigated recent consumer boycott movements against American, British, Danish, and Dutch multinationals in the Middle East, with special focus on companies that took a direct hit. With 300 million people in the region, there is significant purchasing power involved. And there is always the fear that a boycott movement could snowball and cover the entire Muslim world1.3 billion people. There is growing evidence that the turmoil in the Palestinian territories, the war in Iraq, US support for Israel, the Danish cartoons that were considered blasphemous in the Muslim world because of their 
depiction of Muhammad in a derogatory manner, and the Dutch anti-Islam film (Fitna) have fueled anti-Western sentiments in the Middle East obliging western multinationals to battle boycotts and public relations nightmares.

We propose a framework for understanding the phenomenon of product boycotts by first examining the issue from the perspective of boycott organizers. Specifically, we classify the actions that trigger boycott calls into three categories and study the strategies adopted by organizers to generate awareness and compliance with boycott calls. From the corporation perspective, we present a repertoire of six responses to deal with product boycott calls. We draw examples from recent boycott experiences of multinationals in the Middle East. A summary of our model is presented in Figure 1.

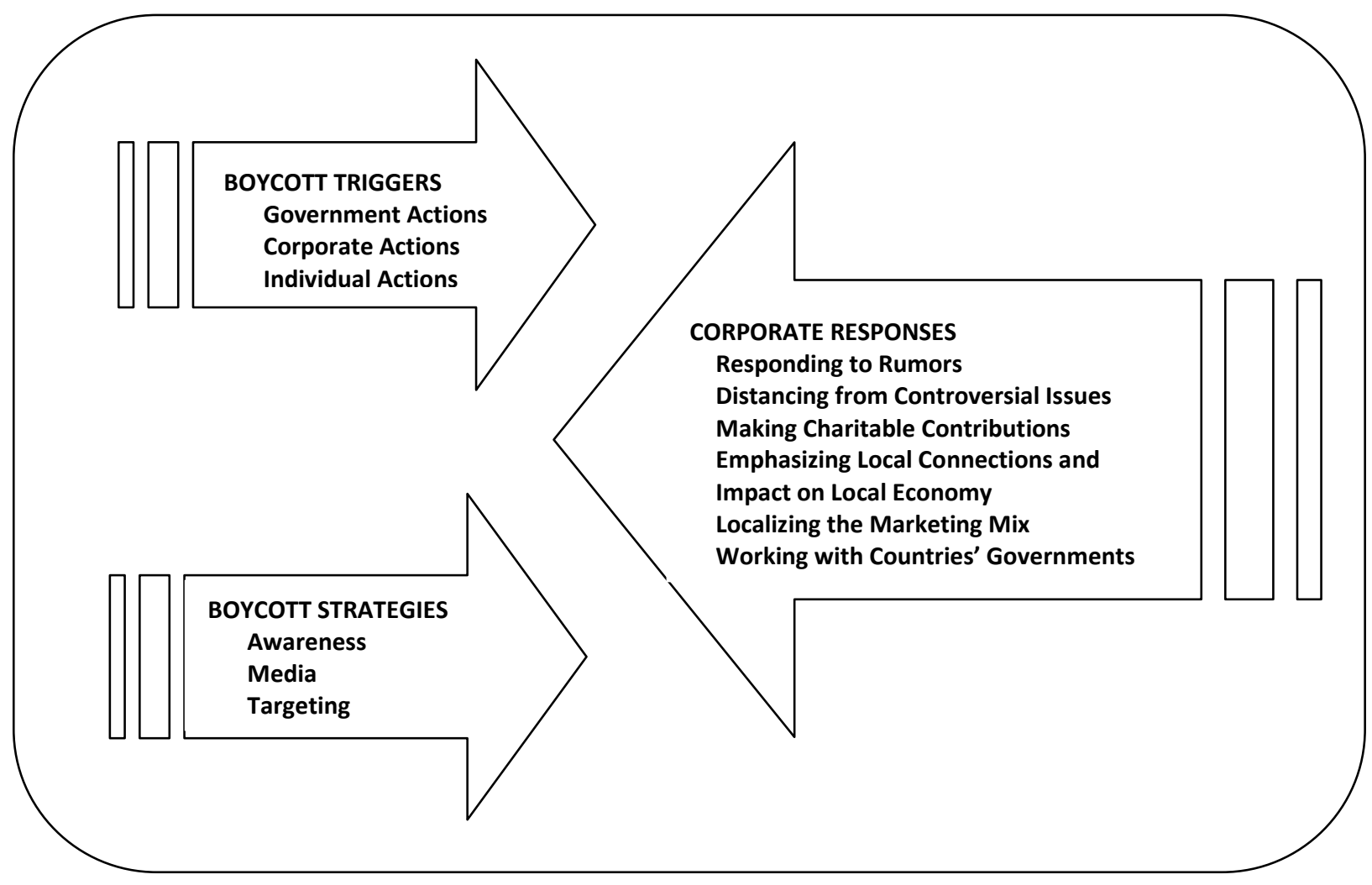

Figure 1: The Boycott Battle

\section{BOYCOTT TRIGGERS}

Every boycott has to have a justification to generate public support. Typically, this justification is used to create a public outcry against the perpetrators (or the most representative symbols of perpetrators) of the actions. It is important to note here that it doesn't really matter much whether the offending actions actually took place or were simply rumored. If the population has the perception that the offending action had taken place, then the reality of the situation doesn't make any significant difference. Three different classes of boycott triggers can be identified: government action (or inaction), corporate action, and individual action.

\section{Governments' Actions}

Government actions include all those instances where the government of a country engages in an act that infuriates the population of another country. The affected population then expresses its displeasure by hurting the economic interests of the offending country by shunning its products. For example, the call to boycott McDonald's, 
Coca Cola, Pepsi, Kentucky Fried Chicken, Pizza Hut, Marlboro, Proctor \& Gamble, and Starbucks in the Middle East during the second Palestinian uprising was triggered in part by the resentment that people felt toward the United States' foreign policy on the Palestinian issue, which is seen as pro-Israel by many factions in the Arab world.

\section{Corporations' Actions}

The second trigger for boycotts is actions of individual corporations. In these instances, corporations (or their partners) either engage in an act that people find offensive or they are (rightly or wrongly) accused of supporting causes that the public finds unacceptable or offensive. An example of the first kind would be the situation that Amazon.com found itself in around November 2002. It was revealed that the Jerusalem Post was donating its slice of the profits derived from the Amazon.com partnership to Israeli soldiers. An ad appearing in the newspaper claimed: "Buy at Amazon.com \& Support Israel". This caused uproar in the Middle East as Amazon was seen as supporting Israel through its association with the Jerusalem Post (Armbruster 2002). Similarly, in May 2001, the Egyptian Pharmacists Syndicate called on drugstores to boycott the products of the U.S. pharmaceutical corporation Eli Lilly, in protest of the company's alleged support of Israel. The syndicate was aggravated by Eli Lilly's distribution of free psychiatric drugs to Holocaust survivors living in Israel (Allam 2001). At times, even some statements made by corporate executives can trigger calls for boycott. For example, in Lebanon, Starbucks was the prime target of a pan-Arab boycott after remarks the company's CEO, Howard Shultz, reportedly made at his Seattle synagogue. Mr. Shultz was quoted saying that Jews needed to tackle rising anti-Semitism worldwide and that the Palestinians needed to do more to fight terrorism (Fisk 2002).

\section{Individuals' Actions}

The third trigger for boycotts is actions of private individuals. These individuals may have no association with the boycotted companies and their actions can still harm corporations in a significant manner through indirect and inferred associations. A classic example in this case is that of the boycott of Danish products after the publication of cartoons in Denmark's largest newspaper, Jyllands-Posten, depicting Prophet Muhammad with a turban shaped like a bomb strapped to his head. The inferred implication of the images, considered blasphemous under Islam, was that Islam preaches violence and condones terrorism. While it was the Danish newspaper that published those images and later on refused to apologize, maintaining that "printing the cartoons was a way to ensure freedom of speech in the face of intimidation from radical Islamists" (Copenhagen Post Online 2005), the price of this action had to be paid by Danish companies (especially dairy product manufacturers such as Arla Foods) who bore the brunt of the boycott calls. Another, more recent, example of an individual's action resulting in a boycott call is that of the Dutch film, Fitna (Arabic word for strife or ordeal). Geert Wilders, a Dutch politician and leader of the anti-immigration Freedom Party, and known for his anti-Islam stance, announced in November 2007 that he planned to release a 15-minute film that would show that Islam's holy book, the Quran, "is an inspiration for intolerance, murder and terror". The movie Fitna was posted online on 3/27/2008 featuring violent images of terror attacks, such as the 9/11 attack in New York and the 3/11 attack in Madrid, intertwined with verses from the Quran. The release of this movie has caused some upheaval in the Middle East, and many countries have called for an economic boycott of the Netherlands.

The action that triggers the boycott also has to have ramifications that apply to a large section of the population. For example, if the actions of a company simply hurt the company's most direct competitors, such actions are unlikely to generate public interest in organizing a boycott. However, if those actions could be packaged into a broader context where they evoke connections to a sensitive issue with mass appeal, they can be used to trigger a boycott. Thus, the basis of the boycott has to be positioned as a public interest issue to be successful. Numerous examples support this assertion:

- During the second Palestinian uprising in 2000, also known as the Al-Aqsa Intifada, there was an unprecedented solidarity with the Palestinian cause expressed in the Middle East through gigantic demonstrations with chants of anti-Israeli and anti-American slogans. In Qatar and UAE, one of the slogans used for the justification was: "Each dollar spent buying an American product is transformed into a bullet to kill our brothers in Palestine" (Gardner 2000). In Syria, billboards around Damascus showed awful 
scenes of Israeli troops demolishing Palestinian refugee camps, with the slogan, "Boycott American products -- Don't be an accomplice" (Macfarquhar 2002). In Morocco, the organizers of the boycott claimed, "They use our money to kill our children in Palestine."

- When Sainsbury of UK, a large retailer, entered the Egyptian market at significantly lower prices, it hurt local companies who had a tough time matching their low prices. Egyptian consumers were obviously delighted to have lower prices and would not have responded to any calls for boycott of Sainsbury simply because it was undercutting domestic Egyptian retailers. However, when rumors started circulating that Sainsbury was Jewish-owned and had Israeli connections, it was easy to portray the company as a broader public enemy which could then be used to support a boycott.

- $\quad$ Major boycott campaigns against McDonald's, Starbucks, and Coca-Cola are almost always positioned on the basis of these companies representing the broader "American imperialism." If the boycotts were organized solely on the basis of how dominant they are because of their superior performance and value proposition, such campaigns would have very limited appeal. Instead, they are presented as symbols of a more nebulous enemy, the American economic dominance on the world stage.

\section{BOYCOTT IMPLEMENTATION STRATEGIES}

We discuss three elements of the implementation strategy employed by the organizers of product boycotts: awareness generation strategies, media strategies, and targeting strategies. For a boycott to be successful, an effective awareness strategy is needed to ensure that the public is made aware of the campaign and that the information is presented in a manner that it clicks with the target audience. Second, a media strategy that utilizes cost-effective mechanisms for spreading the boycott call is essential to a boycott's success. Third, the target of a boycott has to be clearly identified and justified for the boycott to be successful.

\section{Awareness}

A formal awareness strategy used to legitimize a boycott call is to formulate it as a religious decree. Religious leaders have often been involved in calling for product boycotts. For example, to express resentment against the US foreign policy, religious leaders and clerics, from Morocco to Saudi Arabia, have urged consumers not to buy any products associated with the United States. The prominent Muslim cleric, Sheikh Yusuf Al-Qaradawi, issued a fatwa (religious decree) prohibiting eating American burgers and pizza, or drinking Pepsi and Coke. He also displayed a blinking banner on his Web site that read: "Boycott America from Pepsi cans to Boeing" (Macfarquhar 2002). In Egypt, the Grand Imam, Sheikh Mohamed Tantawi, encouraged Muslims to "boycott Israel and all who support it in aggression and injustice"(Farag 2000).

Another approach taken to generate awareness is through use of rumors. Rumors are spread to target specific companies and their products. For example, in Egypt, rumors were spread that McDonald's chairman and CEO, Jack Greenberg, an honorary director of the American-Israel Chamber of Commerce, had approved donating $10 \%$ of profits to Israel. Similarly, a rumor linking Proctor and Gamble's detergent brand (Ariel) to Israel was spread claiming that the detergent was named in honor of Israel's then Prime Minister, Mr. Ariel Sharon, and that its atomic logo was a cleverly disguised Star of David! An equally interesting rumor surfaced in the Middle East about Pepsi. It was claimed that Pepsi was actually an acronym for "Pay Every Penny to Save Israel" (Gulf News 2000).

\section{Media}

The digital age has revolutionized the field of communications. Just as corporations are utilizing the new media to communicate with their target audiences, the boycott organizers are becoming equally savvy at taking advantage of the new tools of communication to spread the word regarding their boycotts. In addition to posting calls for boycotts on prominent religious web sites, organizers have also done a remarkable job of communicating the same through editorial write-ups in influential newspapers and magazines. Grass root efforts at spreading the word have also see an infusion of technology with the use of mass emails, text messaging, blogs, and internet chat rooms. The traditional means of communication such as posters and wall-writings, flyers and pamphlets distributed after prayer meetings, and bumper stickers continue to play an important role in the spread of information regarding 
the boycotts. Finally, T-shirts and hats with catchy slogans have also been used to gain public attention and interest in the boycott campaigns.

\section{Targeting}

Different strategies have been adopted to target different companies across the Middle East. In one approach, a "country-of-origin" argument is used to boycott all brands publicly associated with a target country. For example, in response to the movie Fitna, all Dutch products were generally targeted, with particular emphasis on Dutch dairy products. Other products from Unilever, Shell, and Philips were also listed in boycott calls. Similarly, in the case of Danish cartoons, mass emails listing prominent companies with visible Danish connection (including Arla Foods, Lego Toys, Jovo Toys, Dyrup Paints, Danfoss Pumps, Linberg Eyeglasses, Grundfos Pumps, Bang \& Olufsen, Novo Nordisk, Ochy Perfume, Elelia Perfume, and Ecco Shoes) were circulated. Some companies that had indirect or past Danish connections (such as Kuwaiti Danish Dairy (KDD) and Saudi Dairy \& Foodstuff Co. (SADAFCO)) were targeted as well.

A second targeting approach is to single out individual companies or a small group of companies for boycotts. As mentioned earlier, McDonald's was targeted because of its CEO's alleged links to Israel and the rumored corporate donations to Israel. Similarly, Starbucks was targeted because of its CEO's comments on Israel-Palestinian conflict issue. Amazon was boycotted because of its ties to the Jerusalem Post. Coca- Cola and Pepsi have been singled out by many of the "Muslim Colas" (such as Mecca Cola, Qibla Cola, Muslim Up) for being symbols of American imperialism.

Another targeting strategy that has emerged recently is to organize an umbrella campaign for all boycotts and within that broad campaign, identify "hot button" subjects and then issue appropriate boycott calls targeting individual brands. An example of this was witnessed in Jordan, where major media outlets launched a massive campaign entitled "The Prophet Unites Us" to boycott Danish products. The campaign printed hundreds of thousands of posters displaying pictures of Danish products with a message urging consumers to boycott them. The same campaign was adapted to organize boycott of Dutch products following the release of the movie Fitna. The campaign was launched in Amman under the slogan "Live without It" to boycott both Danish and Dutch products this time. The campaign distributed one million posters together with one million bumper stickers, and thousands of T-shirts and hats with the title of the campaign printed on them, urging consumers to boycott, not only food and dairy products, but anything associated with Denmark and the Netherlands, such as airlines and shipping agencies.

\section{CORPORATE RESPONSES}

Boycotts can have a crippling effect on corporate finances and profitability. Without putting a dollar value to the losses, Coke acknowledged that the Arab boycott, in Egypt and Morocco in particular, had wounded the company. The president of Coca-Cola Africa, Alexander B. Cummings Jr., told analysts that "our business in these countries has been hurt by the boycotting of American brands." Another Coke executive, asked about Mecca-Cola, replied briefly, "We are aware of Mecca, and we have felt the impact of the boycott of American goods" (Tagliabue 2002). Faced by a widespread boycott campaign, violent attacks, and mounting losses, the British retailer Sainsbury's sold its share to its minority partner (Al-Nasharty Group) at a loss of $£ 125 \mathrm{~m}$ ( $\$ 200$ million). Similarly, the boycott of Danish companies cost Arla Foods an estimated $\$ 85$ million in 2006. Given what is at stake for multinationals, it is rather surprising that many companies are ill-prepared to handle such crises. We summarize some common responses available to multinationals to respond to boycott campaigns.

\section{Responding To Rumors}

If left unchecked, rumors have the potential of ruining a company's reputation and goodwill. It is therefore important to counter false rumors in a timely manner before they become "accepted truths." Many companies have responded forcefully to squash the rumor mill. For example, $\mathrm{P} \& \mathrm{G}$ was quick to deny rumors regarding its detergent by stating that Ariel and its logo had been around longer than Prime Minister Sharon and that the sharing of its decades-old name with him was coincidental and that it was "ridiculous to state that there is any association between 
the two" (Grimston 2003). Furthermore, the company changed the six- pointed star logo to a less contentious fourpointed one.

In order to counter the allegations that its CEO Greenberg had approved donating 10 percent of corporate profits to Israel, McDonald's took out full-page ads in Egypt's biggest daily paper, Al-Ahram, denouncing the "ridiculous" rumors. Similarly, when UK's Sainsbury was proclaimed to have Israeli connections, the company ran newspaper advertisements denying any such linkages. "Sainsbury's is a British company owned by 110,000 shareholders," read the advertisement (Farag 2000). Sainsbury's CEO, Sir Peter Davis, also participated in denying the rumors. "I would not have described us as having Israeli connections," Mr. Davis said. "But a few troublemakers in the region said all the profits from our stores were going straight to Israel - despite the fact the stores were not even profitable" (Bowers 2001).

\section{Distancing From Controversial Issues}

If the boycott is not driven any specific action of the company itself, then there is an opportunity to put some distance between the issue and the company. We have seen numerous instances where a company has declared that they should not be held accountable for actions of others. Following the Danish cartoon controversy, the Danish dairy giant, Arla Foods, denounced the cartoons in full-page advertisements taken out in 25 Arab newspapers across the region. The ad read: “...Arla Foods has distanced itself from the Danish newspaper, JyllandsPosten's actions in publishing caricatures of the Prophet Mohammad. We do not agree with the newspaper's reasons for publication..." (Arla Foods 2006). In a similar response to call for boycotts, McDonald's took out newspaper ads in the Middle East condemning the Israeli raids in the Palestinian territories.

When Amazon.com discovered that Jerusalem Post was donating its slice of the profits derived from its partnership to Israeli soldiers (to which consumers in the Middle East objected), the internet bookstore terminated its association with the newspaper. It also asked the newspaper to remove the ads that linked purchases at Amazon.com to supporting Israel. Patty Smith of Amazon told BBC News Online, "We have asked them to take it down and if any sales are made through them they won't receive any commissions" (Armbruster 2002).

After the release of the controversial movie Fitna and fearing a boycott of their products by Muslims, Dutch multinational companies announced that they intend to hold Geert Wilders, the producer of the movie, personally responsible for any loss of profits and markets in the event of a boycott. Two days after the film was released, Dutch companies threatened to sue Wilders. They hired Gerard Spong, one of the top lawyers in the Netherlands, to see whether a court case claiming damages from Wilders would be possible. Two Dutch companies also showed remarkable foresight in condemning the movie very early on. Friesland Foods (dairy products) and Zwanenberg Food Group (meat products) published ads in Jordanian newspaper against Fitna and in support of "The Prophet Unites Us" campaign. The Zwanenberg Food Group said in its ad that it "rejects the opinions and statements" made in Wilders' film, in which he "likens Islam to violence". "We strongly condemn these statements about Islam which we think have no other purpose other than to hurt [Muslims]" (Dutch News 2008). Similarly, the Anglo-Dutch multinational Unilever was proactive about denouncing the film even before it was made. When Wilders announced he was going to make a movie expressing his view on Islam and the Quran, Doekle Terpstra, a member of Unilever board of directors, told the Dutch media in December 2007 that "Geert Wilders is evil, and evil has to be stopped" and called upon the Dutch to "rise in order to stop Wilders from preaching his evil message" (Landen, 2007).

\section{Making Charitable Contributions}

Making charitable contributions to causes that promote welfare in the host country is a commonly used mechanism to portray companies in a favorable light. When sales of McDonald's franchisees' in Saudi Arabia plunged in the first few weeks of the second Intifada, they moved quickly to appease critics by announcing plans to donate approximately 26 cents of the price of each meal sold during the Islamic holy month of Ramadan (November 27-December 26, 2000) to Palestinian children's hospitals. Prince Mishal Bin Khalid, who is one of two franchisees in Saudi Arabia, expected the campaign to raise over \$100,000 (Karon 2000). In Egypt, McDonald's media 
campaign stressed that McDonald's was donating profits -- but not to Israel. Since mid-2001, McDonald's has contributed a portion of its profits to building Egypt's first hospital for children with cancer. In Jordon, the company decided to reach out to the community and help local charities. Marketing manager, Nadia al Dairi, said the franchise donated 10 percent of all sales in the first half of April 2002 to the Hashemite Relief Fund, a Jordanian government charity that gives aid to Palestinians (Gulf News 2002).

\section{Emphasizing Local Connections And Impact On Local Economy}

As noted in the opening quote of this paper, Coca-Cola responded to boycott calls by emphasizing its local roots. Similarly, in response to rumors regarding its alleged donations to Israel, McDonald's took out ads in local newspapers in Egypt emphasizing its local connections and how the rumors threatened the future and source of income of over 3,000 Egyptian workers. In Morocco, McDonald's published press releases which stated: "The Morocco branch operates with Moroccan capital, employs Moroccan youth and abides by the teachings of Islam in terms of food processing" (Al-Aly 2002).

\section{Localizing The Marketing Mix}

Companies have also responded to boycott calls by altering their marketing mix - by introducing new products with strong local flavor, by including locally popular endorsers in their ad campaigns, by offering localized promotions, and even by de-emphasizing their American brand name. For example, in the midst of the Intifada movement, McDonald's in Egypt responded by adding McFalafel to its menu. This was clearly in an attempt to attract local customers and boost sales. The company also hired an Egyptian singer, whose nationalistic song "I hate Israel" topped the charts for months, to promote the sandwich. In March 2002, McDonald's decided to emphasize a new corporate brand name in Egypt (Manfoods), in an attempt to dodge corporation's perceived identity of being pro-Israel (Al-Quds Al-Arabi 2002). In March 2003, while the US-led coalition forces were invading Iraq, McDonald's introduced a product in the Middle East - the McArabia. The chicken sandwich, on Arabian-style bread mixed with aromatic black seeds, was intended to "re-launch McDonald's in the Muslim world" (Tagliabue2003). "The idea was to launch something for the local taste. There were so many options of what to call it, but the best was McArabia," said George Khawam, Kuwait marketing director for McDonald's, which has more than 30 restaurants in the emirate (Leiby 2003). Similarly, in an effort to further ingratiate itself with Arab consumers and avert a massive boycott, Coca Cola signed partnerships with a Saudi singer and an Omani rally driver, and sponsored the Palestinian, Lebanese, and Saudi national soccer teams.

Kuwait Food Co. (Americana), that holds 13 franchises and 543 outlets for fast food chains like KFC, Pizza Hut, Hardee's, Subway, and Baskin Robbins in 11 Arab countries, also suffered a slump as a result of boycott calls. The company launched a multi-million dollar advertising campaign accentuating it was 100 percent Arab owned and operated. The campaign slogan was: "Americana ... 100\% Arab" (Al-Sharq Al-Awsat 2002). Similarly, to counter rumors that it was somehow Jewish or supportive of Israel, Sainsbury replaced the soft, soothing music played in its stores with Quran recitations.

After the second publication of Danish cartoons, Arla responded differently. Instead of running emotional ads like they did during the first cartoon crisis in 2006, the company decided to restructure its operations in the region. In May 2008, Arla relocated its Middle East management from Copenhagen to Dubai; and a new team moved closer to the markets in order to integrate the five subsidiaries and joint ventures under director Finn Hansen. "We believe in a profitable future in the Middle East where we have strong quality brands for which consumers are willing to pay a premium," said Mr. Hansen. "But we must also accept that the Middle East is no longer the same stable market as it once was. This is why we're adjusting our business model to face up to any future fluctuations. Simplification and focus are the key words for the new strategic focus in the region," he explained (Arla Foods 2008). 


\section{Working With Countries' Governments}

Corporations often seek help (overtly or covertly) from their own governments to help avoid boycotts or to mitigate the effect of boycotts. As an example, the managing director of Arla Foods, Peder Tuborgh, sought his government's help when the controversy regarding the Danish cartoons sparked calls for boycott: "I would ask the government to immediately enter a positive dialogue with the many millions of Muslims who feel offended by Denmark. I'm not sure if we have been quick enough at home to understand the scope of this" (Castle 2006). In this instance, even the European Union stepped in and threatened Saudi Arabia with taking the matter to the World Trade Organization if the authorities supported the growing boycott of Danish products. The EU Trade Commissioner plainly warned the Saudis that any Danish boycott would be a boycott of the European Union, and would have serious consequences (Copenhagen Post Online 2006).

Although clear evidence is sketchy, it is very likely that American firms or maybe even the American administration had sought the help of home governments to deflect boycotts. It is interesting to note that most Gulf governments have largely distanced themselves from the boycott calls. Most have tight economic and political ties with the United States, and some have U.S. troops stationed in their territory. Moreover, the local franchisees have close connections with the ruling regimes. For example, most of McDonald's outlets in Saudi Arabia are owned by a prince from the royal family (Prince Mishal Bin Khalid). Americana is owned by a very influential billionaire, Jassem Al-Khorafi, who is the Kuwaiti parliament speaker and has strong ties with the ruling family.

\section{CONCLUSION}

Product boycotts can have dire consequences for multinational companies and their brands. As we have demonstrated, the triggers include government, corporate and individual actions. The boycott strategies can be classified into three main domains: awareness, media and targeting. Corporate responses include responding to rumors, distancing the company from controversial issues, making charitable contributions, emphasizing local connections, demonstrating the impact on the local economy, localizing the marketing mix and influencing government actions.

In many of the examples cited in the paper, it appears that the companies involved were caught somewhat unprepared and at least in some instances dealt with the boycotts on a trial and error basis. As boycotts are very complex and have many different causes, it is probably not possible to prescribe a one-size-fits-all solution for dealing effectively with the range of boycotts that are possible. However, one recommendation that we make is that multinational companies develop contingency plans for boycotts. The potential economic impact of a boycott is such that an investment of time and effort is justified. Also, it appears that knowledge of the local situation is critical. Our paper draws on the situation in the Middle East. Any effective response to a boycott requires substantial knowledge of the region's economic, political and religious situation. Such knowledge may enable a company to take early, preventive measures in an attempt to avoid a boycott.

Ultimately, multinational companies need to continuously monitor all developments that affect their markets, including government actions, corporate actions and individual actions. While responding to every trivial development is impractical, we also believe that early and categorical responses are most effective as demonstrated by the Dutch example.

\section{AUTHOR INFORMATION}

Kjell R. Knudsen (Ph.D. University of Minnesota) is Associate Professor of Policy and Administrative Behavior and the Dean of the Labovitz School of Business and Economics at the University of Minnesota Duluth. Before joining UMD, he served as Project Manager at the Royal Norwegian Council for Industrial and Scientific Research in Oslo, Norway. He also served for several years as a consultant to the Norwegian Center for Organizational Learning in Oslo, Norway as well as the Foundation for Strategic and Industrial Research in Trondheim, Norway. His research interests include policy formulation and implementation, leadership, management culture, organizational learning, and economic development. 
Praveen Aggarwal (Ph.D. Syracuse University) is Professor of Marketing and Chair of the Department of Marketing in the Labovitz School of Business \& Economics at the University of Minnesota Duluth. His research interests are in the areas of consumer decision-making processes, strategic marketing, and price and non-price promotions. Praveen has several years of work experience as a senior executive in the food products industry in India.

Ahmed Maamoun (Ph.D. California Coast University) is Assistant Professor of Marketing in the Labovitz School of Business and Economics at the University of Minnesota Duluth. Ahmed has several years of experience in the field of international business, acquired in multinational companies in the Middle East and New Zealand. He is interested in studying international corporations and how multinationals adjust their strategies to respond to cultural and socio-political differences.

\section{REFERENCES}

1. Al-Aly, Nizar (2002), "US Boycott Gains Momentum in Morocco," Asheville Global Report, May 23-29.

2. Allam, Rana (2001), "Brash Boycott?" Al-Ahram Weekly, May 17-23.

3. Al-Sharq Al-Awsat (2002), "Americana's Profits Increase in the First Half of the Year," August 11.

4. Al-Quds Al-Arabi (2002), "McDonald's Egypt Changes its Name to Manfoods," April 18.

5. Arla Foods (2006), "Arla Attempts a Comeback in the Middle East," March 20, Press release.

6. Arla Foods (2008), "Arla Streamlines its International Organization," May 23, Press release.

7. $\quad$ Armbruster, Stefan (2002), “Amazon Denies Backing Israel,” BBC News, November 15.

8. Bowers, Simon (2001), "Protests Force Sainsbury Out of Egypt with £125m Loss," The Guardian, April 10.

9. Castle, Stephen (2006), "Mohamed Cartoons Provoke Bomb Threats Against Danish Newspaper," The Independent, February 1.

10. Copenhagen Post Online (2005), "Muslim Organization Calls for Boycott of Denmark," December 28.

11. Copenhagen Post Online (2006), "EU Steps into Mid-East Conflict," January 30.

12. Dutch News (2008), "Dutch Firms Advertise Against Fitna," June 23.

13. Farag, Fatemah (2000), "Palestinian Flag Over the Nile," Al-Ahram Weekly, October 19 - 25.

14. Fisk, Robert (2002), "Starbucks the Target of Arab Boycott for its Growing Links to Israel," The Independent, June 14.

15. Friedman, Monroe (1985), "Consumer Boycotts in the United States, 1970-1980: Contemporary Events in Historical Perspective," Journal of Consumer Affairs, Vol. 19, pp. 96-117.

16. Gardner, Frank (2000), "Saudi Burgers to Help Palestinians," BBC News, November 28.

17. Grimston, Jack (2003), "British Muslims Find Things Go Better with Mecca," Times Online, January 19.

18. Gulf News (2000), "Arab Push to Boycott U.S. Products Only Symbolic," November 29.

19. Gulf News (2002), "Drive to Boycott U.S. Goods Picks Up Steam," April 30.

20. Karon, Tony (2000), “Official Sandwich of the Intifada?” Time, November 29.

21. Landen, Thomas (2007), "Dutch Unilever Director Wants Wilders Stopped," The Brussels Journal, December 8.

22. Leiby, Richard (2003), "You Want Falafel with That? After a Massive Buildup, McDonald's McArabia Sandwich Lands in Kuwait," Washington Post, March 17.

23. Macfarquhar, Neil (2002), "An Anti-American Boycott is Growing in the Arab World," New York Times, May 10.

24. Tagliabue, John, (2002) "They Choke On Coke, But Savor Mecca-Cola," New York Times, December 31.

25. Tagliabue, John (2003), "U.S. Brands Abroad Are Feeling Global Tension," New York Times, March 15. 


\section{NOTES}

